\title{
EFFECT OF BIO AND ORGANIC N FERTILIZER AS A PARTIAL SUBSTITUTE FOR MINERAL-N FERTILIZER ON YIELD OF PEANUT (Arachis hypogaea L.)
}

\author{
Magda A. Ewais, Sahar M. Zakaria and Soha S. M. Mostafa \\ Soils, Water and Environ. Res., Inst., Agric. Res. Center, Giza, Egypt
}

Received: Oct. 31, 2016

Accepted: Nov. 21,2016

\begin{abstract}
Two field experiments were carried out at Ismailia Agricultural Research Station, Agricultural Research Center (ARC), Egypt, located at lat. 30 $35^{\prime} 30^{\prime \prime} \mathrm{N}$, long. $32^{\circ} 14^{\prime}$ 50" E. during two successive summer seasons of 2013 and 2014, to study the effect of partial replacement of mineral $N$ fertilizer by organic or bio-fertilizers on soil microbial activities, some seed macro nutrients content, growth characters, yield and yield components of peanut. Results of this study showed that inoculation with cyanobacteria enhances the soil biological activity in terms of increasing the total bacterial, total cyanobacterial counts, $\mathrm{CO}_{2}$ evolution, dehydrogenase and nitrogenase activities. Combined inoculation of cyanobacteria at 20 or $30 \mathrm{~L} / \mathrm{fed}$ with $50 \%$ of the recommended mineral $N+50 \%$ as organic $N$ gave the highest nitrogenase and dehydrogenase activities and $\mathrm{CO}_{2}$ evolution in rhizosphere as well as the macro nutrient content in seeds of peanut plants. The highest significant increases for all growth characters, yield and yield components of peanut were also recorded by the same treatment.
\end{abstract}

Key words: Cyanobacteria, Organic N, Mineral N, Yield Parameters, Quality of seeds, peanut

\section{INTRODUCTION}

Peanut (Arachis hypogaea L.) is considered one of the most important edible oil crops in Egypt, due to its seeds' high nutritive value for humans, as well as the produced cake and the green leafy hay for feeding livestock, in addition to the importance of the seed oil for industrial purposes. The main growing areas are located in the north of the country; they include reclaimed desert to the east and west of the Nile Delta. Peanut seeds are characterized by their high oil content $50 \%$, which is utilized in different industries, besides they contain $26-28 \%$ protein, 20\% carbohydrates and $5 \%$ fiber (Fageria et al. 1997).

Fertilization is one of the most important factors that increase plant production. Nitrogen is an integral component of many compounds, including chlorophyll and enzymes, as well as amino acids and related proteins. It is also known that nitrogen is an essential element for achieving high and stable yields and increased grain proteins. Peanut has one of the highest nitrogen requirements among the most agronomic crops (Boroomandan et al. 2009).

Cyanobacteria can be a useful potential bio fertilizer whether in solid or liquid forms. Cyanobacteria can both photosynthesize and fix $\mathrm{N}$ with great adaptability to various soil types (Mishra and Pabbi, 2004). They have the unique ability to fix $\mathrm{N}$ from the atmosphere through coupling photosynthesis to $\mathrm{N}$ fixation. Bio fertilizers are typically environmentally safe, cheaper and could satisfy the nutrient demands of crops (Badawy et al. 1996). El Gaml (2006) explained that bio fertilization using cyanobacteria led to increases in the soil microbial community such as soil fungi, actinomycetes, and soil bacteria. Increasing soil microbial activity led to increased organic matter content, dehydrogenase and nitrogenase activities and subsequently improved soil fertility and plant growth performance (Hassan et al. 2008). In addition 
Ewais, et al.,

to contributing nitrogen, cyanobacteria benefit crop plants also by producing various growth promoting substances, like gibberellins, auxins like indole-3-acetic acid, indole-3-propionic acid, etc., vitamin $\mathrm{B}_{12}$, free amino acids like serine, arginine, glycine ,aspartic acid, threonine, glutamic acid, etc., extra- and intra-cellular polysaccharides like xylose, galactose, fructose, etc. Such substances have several beneficial effects like improved soil structure, stimulation of growth of crop plants as well as useful bacteria, chelation of heavy metals (El-Kholy et al. 2005). Certain cyanobacteria have been found not only to grow in such inhospitable ecosystems, but also improve the physico-chemical properties of the soil by enriching them with carbon, nitrogen, available phosphorus, etc. Considerable reduction of exchangeable sodium, soil $\mathrm{pH}$ (towards neutrality) and conductivity, by these cyanobacteria has been reported. Cyanobacteria also reduce sodium ion content of the soil by making calcium ions available through solubilisation of calcium carbonate nodules, possibly by releasing various organic acids like, oxalic-, oxaloacetic-, lactic-, succinic acids, etc. (Aref and El-Kassas 2006).

The aim of this study was to replace part of chemical $\mathrm{N}$ fertilizers by bio or organic fertilizer firstly for clean agricultural product and increasing yield and yield components and secondly for improving biological properties of these sandy soils.

\section{MATERIALS AND METHODS Field Experiments}

Two field experiments were carried out at Ismailia Agricultural Research Station, Agricultural Research Center (ARC), Egypt, during two successive summer seasons of 2013 and 2014, to study the effect of partial replacement of chemical $\mathrm{N}$ fertilizers with organic fertilizers and to identify the best concentration of biological agent to serve as bio fertilizer on peanut plant growth, yield and yield attributes, under sandy soil conditions. Chemical analyses of the experimental soil are shown in Table (1). Chemical analyses of compost are also illustrated in Table (2). Compost was added and mixed thoroughly with soil surface two weeks before seeding.

Table (1): Mechanical and chemical properties of the studied soil.

\begin{tabular}{|c|c|c|c|c|c|c|c|c|}
\hline \multicolumn{9}{|c|}{ Mechanical and chemical properties } \\
\hline $\begin{array}{l}\text { Coarse } \\
\text { sand } \\
\%\end{array}$ & $\begin{array}{l}\text { Fine } \\
\text { sand } \\
\%\end{array}$ & $\begin{array}{l}\text { Silt } \\
\%\end{array}$ & $\begin{array}{c}\text { Clay } \\
\%\end{array}$ & $\begin{array}{l}\text { Textural } \\
\text { class }\end{array}$ & $\begin{array}{c}\mathrm{Ca} \mathrm{CO}_{3} \\
\%\end{array}$ & $\begin{array}{c}\text { Organic } \\
\text { matter } \\
\%\end{array}$ & $\begin{array}{c}\mathrm{pH} \\
(1: 2.5)\end{array}$ & $\begin{array}{c}\mathrm{EC}\left(\mathrm{dSm}^{-1}\right) \\
\text { in soil paste } \\
\text { extract }\end{array}$ \\
\hline 45.20 & 39.5 & 9.34 & 5.96 & Sandy & 2.4 & 0.12 & 7.68 & 3.8 \\
\hline \multicolumn{9}{|c|}{ Soluble ions in soil paste extract (meq $\mathrm{I}^{-1}$ ) } \\
\hline $\mathrm{Ca}^{++}$ & $\mathrm{Mg}^{++}$ & & $\mathrm{Na}^{+}$ & $\mathrm{K}^{+}$ & $\mathrm{CO}_{3}^{--}$ & $\mathrm{HCO}_{3}^{-}$ & $\mathrm{Cl}^{-}$ & $\mathrm{SO}_{4}^{--}$ \\
\hline 9.7 & 8.7 & & 15.1 & 4.5 & - & 14.2 & 10.2 & 13.6 \\
\hline \multicolumn{9}{|c|}{ Available macronutrients $\left(\mathrm{mg} \mathrm{Kg}^{-1}\right)$} \\
\hline \multicolumn{3}{|c|}{$\mathrm{N}$} & \multicolumn{3}{|c|}{$P$} & \multicolumn{3}{|c|}{ K } \\
\hline \multicolumn{3}{|c|}{25} & \multicolumn{3}{|c|}{7.0} & \multicolumn{3}{|c|}{250} \\
\hline
\end{tabular}


Table (2). Physical and chemical properties of the used compost (averaged in 2013 and2014 seasons)

\begin{tabular}{|l|c|}
\hline \multicolumn{1}{|c|}{ Properties } & Value \\
\hline EC value (1:10) $\left(\mathrm{dSm}^{-1}\right)$ & 7.90 \\
\hline pH value (1:10) & 6.70 \\
\hline Moisture content (\%) & 28.00 \\
\hline Organic matter (\%) & 44.48 \\
\hline Organic carbon (\%) & 25.80 \\
\hline Total nitrogen (\%) & 1.42 \\
\hline C/N ratio & 18.20 \\
\hline Soluble ammonium-N mg/kg & 615.00 \\
\hline Soluble nitrate-N mg/kg & 362.00 \\
\hline Total P (\%) & 0.57 \\
\hline Total K (\%) & 0.82 \\
\hline
\end{tabular}

\section{Algal strain sources, growth conditions and culture characterizations}

$\mathrm{N}_{2}$-fixing (Nostoc muscorum, Nostoc humifusum, Anabaena oryzae and Wollea $\mathrm{sp}$ ) and non $\mathrm{N}_{2}$-fixing (Phormedium sp. and Spirulina platensis) cyanobacteria strains were obtained from the Microbiology Department, Soils, Water and Environment Res. Inst., Agric. Res., Center. The cyanobacterial strains were grown separately on BG11 medium (Rippka et al., 1979) except the Spirulina platensis, which was grown on Zarrouk medium (Zarrouk, 1966). The cultures were incubated in growth chamber under continuous illumination (2000 lux) and the temperature of $25^{\circ} \mathrm{C} \pm 2^{\circ} \mathrm{C}$ for all strains except the mesophilic alga Spirulina platensis, which was grown on $35^{\circ} \mathrm{C} \pm 2^{\circ} \mathrm{C}$.
Culture growth parameters were shown in Table (3). The $\mathrm{pH}$ values and algal dry weight (DW) were estimated according to Vonshak (1986). Culture concentration was determined as optical density (OD) by spectrophotometer at $560 \mathrm{~nm}$ (Leduy and Therien, 1977). Chlorophyll-a (Ch-a) was determined spectrophotometrically after extraction by absolute methanol as reported by Vonshak and Richmond (1988).

\section{The studied treatments may be listed as follows:}

$\mathrm{T}_{1}-100 \%$ of the recommended mineral $\mathrm{N}$ $(30 \mathrm{kgN} / \mathrm{fed})$ control:

$\mathrm{T}_{2}-75 \%$ of the recommended mineral $\mathrm{N}$ $\left(22.5 \mathrm{kgNfed}^{-1}\right)+$ cyanobacteria $(15 \mathrm{l} / \mathrm{fed})$ as soil drench

$\mathrm{T}_{3}-75 \%$ of the recommended mineral $\mathrm{N}+$ cyanobacteria (20 l/fed) as soil drench

$\mathrm{T}_{4}-75 \%$ of the recommended mineral $\mathrm{N}+$ cyanobacteria (30 l/fed) as soil drench 
$\mathrm{T}_{5}-100 \%$ organic $\mathrm{N}\left(30 \mathrm{~kg} \mathrm{Nfed}^{-1}\right)(2.12 \mathrm{t}$ compost fed $^{-1}$ ).

$\mathrm{T}_{6}-75 \%$ organic $\mathrm{N}\left(22.5 \mathrm{kgNfed}^{-1}\right)(1.59 \mathrm{t}$ compost fed $\left.^{-1}\right)+$ cyanobacteria (15 l/fed) as soil drench

$\mathrm{T}_{7}-75 \%$ organic $\mathrm{N}$ (compost) + cyanobacteria (20 l/fed) as soil drench

$\mathrm{T}_{8}-75 \%$ organic $\mathrm{N}$ (compost) + cyanobacteria (30 l/fed) as soil drench

$\mathrm{T}_{9}-50 \% \quad \mathrm{~N}-$ mineral $\left(15 \mathrm{kgNfed}^{-1}\right) \quad+50 \%$ organic $\mathrm{N}\left(15 \mathrm{~kg} \mathrm{Nfed}^{-1}\right)$ (1.06 t compost $\mathrm{fed}^{-1}$ ).

$\mathrm{T}_{10}-50 \%$ of the recommended mineral $\mathrm{N}$ $+50 \%$ organic $\mathrm{N}$ (compost) + cyanobacteria ( $15 \mathrm{l} / \mathrm{fed}$ ) as soil drench

$\mathrm{T}_{11}-50 \%$ of the recommended mineral $\mathrm{N}$ $+50 \%$ organic $\mathrm{N}$ (compost) + cyanobacteria (20 l/fed) as soil drench

$\mathrm{T}_{12}-50 \%$ of the recommended mineral $\mathrm{N}$ $+50 \%$ organic $\mathrm{N}$ (compost) + cyanobacteria (30 l/fed) as soil drench

\section{The experimental design:}

The experiment was laid out in a complete randomized block design with three replicates with a plot area of $10.5 \mathrm{~m}^{2}$ (1/400 feddan).Superphosphate $\left(15 \% \mathrm{P}_{2} \mathrm{O}_{5}\right)$ at a rate of $200 \mathrm{~kg} / \mathrm{fed}$. and potassium sulfate $\left(48 \% \mathrm{~K}_{2} \mathrm{O}\right)$ at a rate of $50 \mathrm{~kg} / \mathrm{fed}$ were incorporated into the soil for all studied treatments before sowing. Ammonium sulphate $(20.5 \% \mathrm{~N})$ as mineral $\mathrm{N}$-fertilizer treatments were added in three equal doses, i.e., at 30,45 and 60 days after sowing. The mixture of algal culture suspension was used for soil drench application at a rate of
15,20 or $30 \mid \mathrm{fed}^{-1}$ which were divided into two equal portions for two doses. The first was with the first irrigation after 21 days from sowing and the second was at the flowering stage.Peanut seeds (variety Giza 6) were provided by the Oil Crops Research Department, Field Crops Research Institute, ARC, Giza, Egypt.

At harvest, ten guarded plants were randomly taken from the second inner two rows of each experimental unit to determine plant height $(\mathrm{cm})$ and yield components, namely, pod number/plant, seed number/plant, weight of pods and seeds/plant, 100- pod and seed weight, total pod and seed yield ( $\mathrm{kg} / \mathrm{fed}$ ) as well as crude protein and shelling percentages.

\section{Soil Biological Analysis:}

Soil biological activities were measured after the second soil drench addition. The $\mathrm{CO}_{2}$ evolution was determined according to Gaur et al. (1971), total bacterial count was performed on nutrient agar using the spread plate method (APHA, 1992) and total cyanobacterial counts were conducted by plating ten-fold serial soil suspensiondilutions in triplicate onto agarized BG11 medium (Stanier et al. 1971). Soil enzymes, i.e., dehydrogenase activity (DHA), was estimated according to Casida et al. (1964), while nitrogenase activity was measured by acetylene reduction assay as described by Dart et al. (1972).

Table (3): The algal growth parameters (Mean values of $2013 \& 2014$ seasons).

\begin{tabular}{|l|c|c|c|c|c|c|}
\hline Properties & $\begin{array}{c}\text { Nostoc } \\
\text { muscorum }\end{array}$ & $\begin{array}{c}\text { Spirulina } \\
\text { platensis }\end{array}$ & $\begin{array}{c}\text { Anabaena } \\
\text { oryzae }\end{array}$ & Wollea sp. & $\begin{array}{c}\text { Nostoc } \\
\text { humifusum }\end{array}$ & $\begin{array}{c}\text { Phormedium } \\
\text { sp. }\end{array}$ \\
\hline $\mathrm{pH}$ & 8.11 & 10.16 & 7.14 & 6.82 & 8.05 & 8.67 \\
\hline $\mathrm{OD}$ & 1.19 & 2.77 & 0.87 & 2.40 & 1.67 & 2.09 \\
\hline $\mathrm{T}-\mathrm{Ch}\left(\mathrm{mgl}^{-1}\right)$ & 5.26 & 11.63 & 4.03 & 9.82 & 7.56 & 3.00 \\
\hline $\mathrm{DW}\left(\mathrm{mgl}^{-1}\right)$ & 760.96 & 1772.80 & 557.76 & 1532.80 & 1065.60 & 1334.40 \\
\hline
\end{tabular}




\section{Methods of analysis}

- Soil properties and compost traits were determined according to Piper (1950) and Page et al. (1982).

- The seeds of harvested plants were air-dried, oven -dried at $70 \circ \mathrm{c}$ weighted, ground and kept for chemical analysis, the oven dried plant materials were wet digested using a mixture of pure $\mathrm{HClO}_{4}$ and $\mathrm{H}_{2} \mathrm{SO}_{4}$ at a ratio of 1:1, according to Chapman and Pratt (1961). Total nitrogen, phosphorous and potassium was determined in the seed, according to Chapman and Pratt (1961).

- Seed crude protein percentage was calculated by multiplying N\% by 6.25 (A.O.A.C., 1990).

- Oil (\% )in seeds was determined by using Soxhlet apparatus and petroleum ether as an organic solvent as described by A.O.A.C. (1990).

- Oil yield ( $\mathrm{kg} / \mathrm{fed}$ ) was estimated by multiplying seed yield ( $\mathrm{kg} / \mathrm{fed}$.) by seed oil percentage.

The experimental data obtained were subjected to analysis of variance (ANOVA), according to the procedures outlined by Snedecor and Cochran (1980).

\section{RESULTS AND DISCUSSION \\ I-Yield and yield components}

Plant height, pod and seed number/plant, hundred pod and seed weight as well as pod and seed weight/plant of peanut crop as affected by inoculation with cyanobacteria in combination with inorganic nitrogen and/or compost (organic N) are given in Table (4) and Fig. (1). Results showed that maximum enhancement was observed in plants treated with $50 \% \mathrm{~N}$ - mineral $+50 \%$ $\mathrm{N}$ - Org. and inoculation with cyanobacteria at $30 \mathrm{~L} / \mathrm{fed}\left(\mathrm{T}_{12}\right)$. Inoculation with cyanobacteria with application of either the $\mathrm{N}$ - mineral or organic $\mathrm{N}$ increased plant height, pod and seed number/plant, pod and seed weight/plant, as well as 100-seed weight, 100-pod weight and seed weight comparing with those of the inorganic nitrogen or compost when used alone. Similar results were reported by Abd El-Moniem et al. (2008) and Zaki et al. (2010). These increases may be attributed to the beneficial effects of nitrogen on stimulating the meristmatic activity for producing more tissues and organs, since nitrogen plays major roles in the synthesis of structural proteins and other several macro molecules, in addition to its vital contribution in several biochemical processes in the plant related to growth (Marschner 1995). Moreover, the positive effect on growth traits by using compost manure might be related to the improvement of physical conditions of the soil and supplying plant with mineral nutrients, i.e., N.P.K and micronutrients (Fe, $\mathrm{Zn}$ and $\mathrm{Mn}$ ), organic matter as well as humic acid content (Rechcigl, 1995). Also, $\left(T_{12}\right)$ produced the greatest plant height, pod and seed number/plant, pod and seed weight/plant, as well as hundred pod and seed weight. This superior treatment induced increases in these parameters over that of $100 \% \mathrm{~N}$ - mineral treatment $\left(\mathrm{T}_{1}\right)$ reached about $(6.15,8.06,14.61,15.22,14.17$, 5and10.13\%) respectively.

Regarding the effect of inoculation treatments on peanut yield components, data in Table (4) illustrated also that cyanobacteria inoculation in combination with any of the tested treatments caused increases in all peanut yield components, as compared with the uninoculated treatments. These results may be attributed to that cyanobacteria release promoting substances mainly indole acetic acid, gibbrellines and cytokinines. These promotive effects of cyanobacteria could stimulate plant growth, absorption of nutrients and their efficiency, as well as the metabolism of photosynthesis. These results stand in accordance with those obtained by Maqubela and Menkeni (2009). However, peanut plants exerted high responses to the combined application of cyanobacteria $30 \mathrm{~L} / \mathrm{fed}$ as soil drench with $50 \%$ of the recommended mineral $\mathrm{N}$ fertilizer $+50 \%$ 


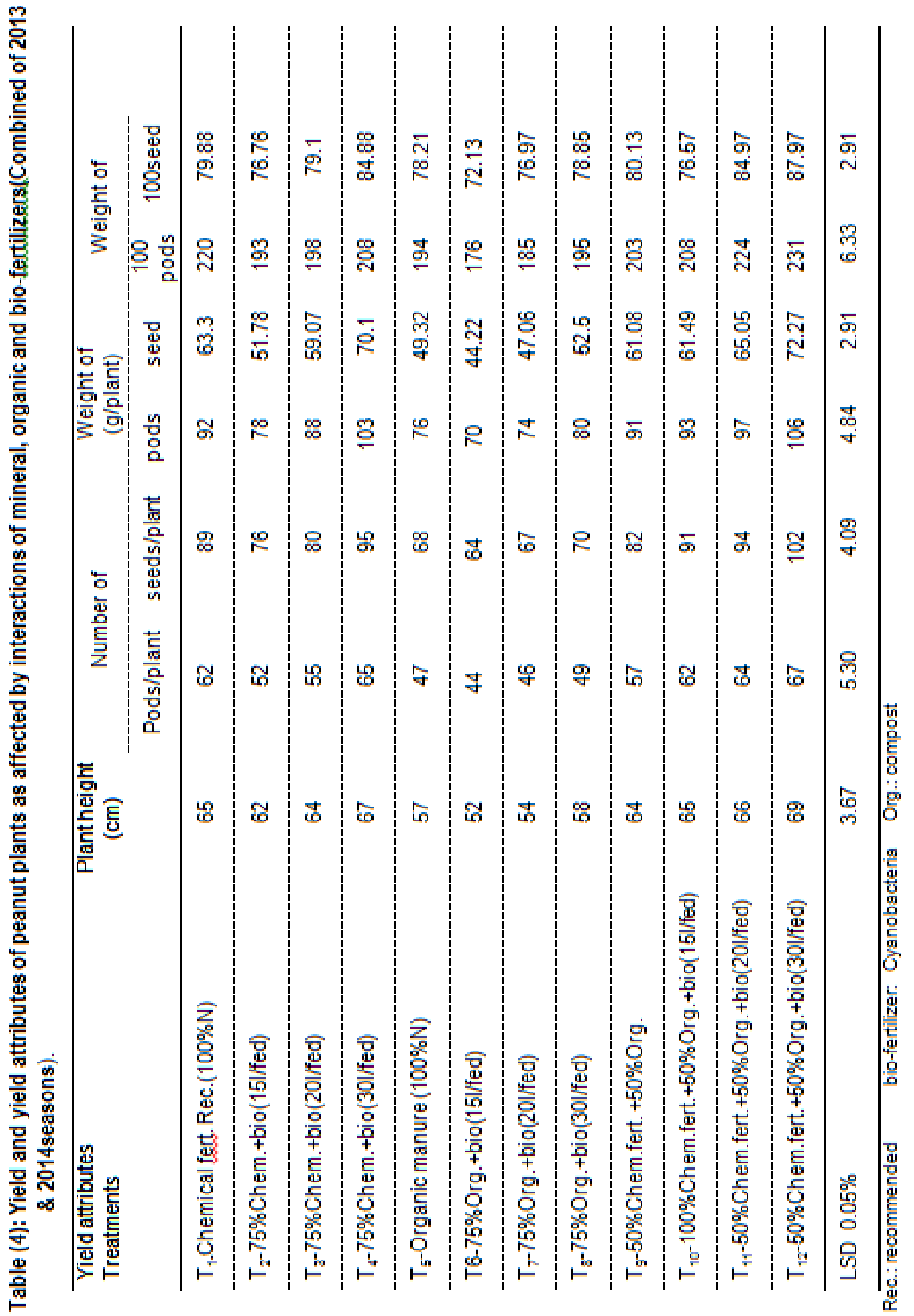




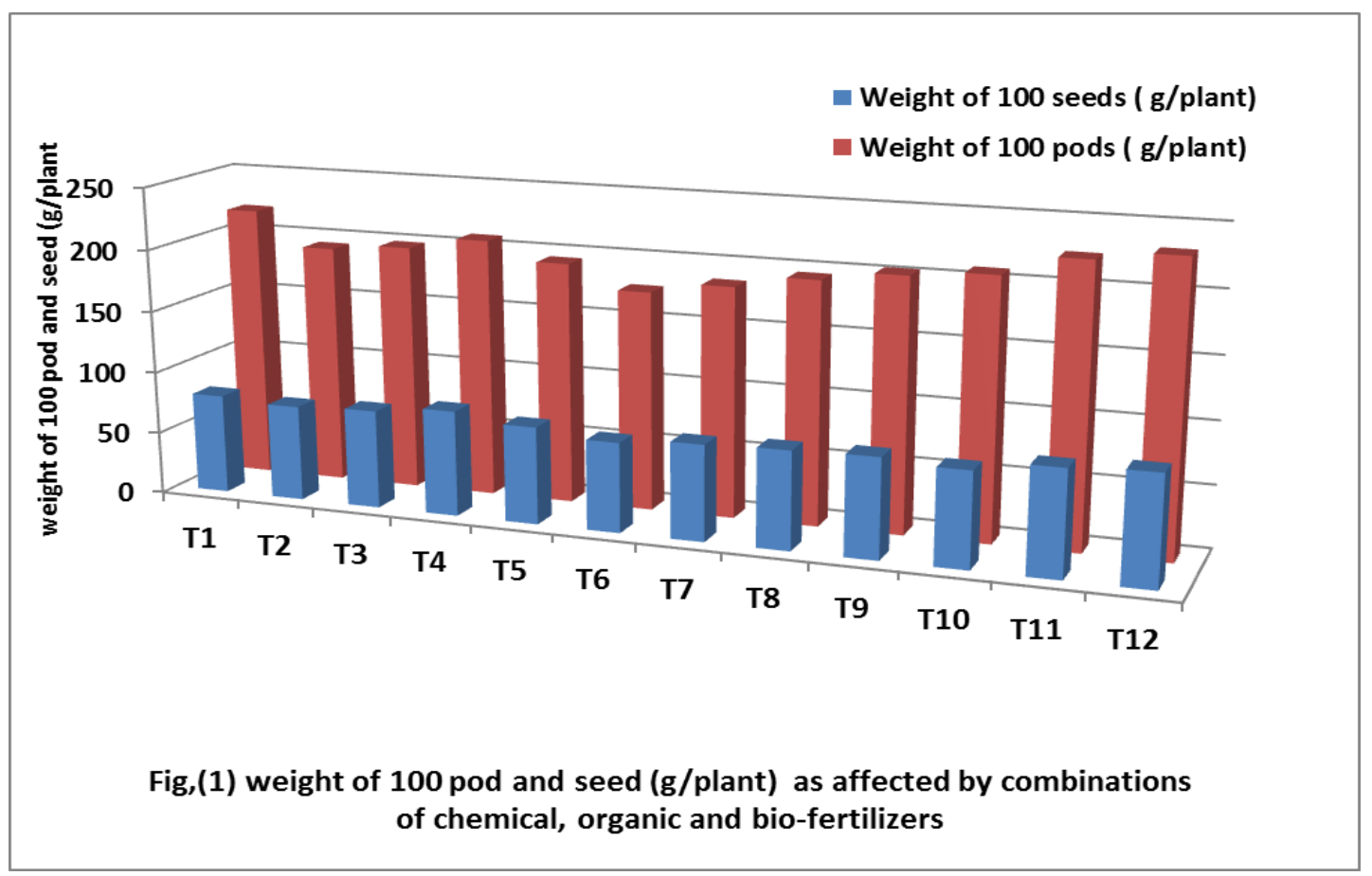

compost being the best treatment for enhancing plant growth followed by the same application with $75 \%$ of the recommended mineral $\mathrm{N}$ fertilizer. In fact, cyanobacteria have been shown to greatly improve the productivity and quality of many legumes, when they inoculated with rhizobia. This synergistic effect may be elucidated by their ability to enhance the $\mathrm{N}_{2}-$ fixation performance, as well as nutrients availability and uptake from soil, which results in the production of substances like hormones, siderophores, phosphate solubilization and improvement of nutrients and water uptake. The acts of these algae include: (1) Increase in soil pores with having filamentous structure and production of adhesive substances. (2) Excretion of growth-promoting substances such as hormones (auxin, gibberellin), vitamins, amino acids. (3) Increase in water holding capacity through their jelly structure (Roger and Reynaud 1982). (4) Increase in soil biomass after their death and decomposition. (5) Increase in soil phosphate by excretion of organic acids. Also Data in Table (5) and Fig. (2) exhibited that yield was significantly influenced by inoculation with cyanobacteria in combination with inorganic nitrogen and/or compost. It was found that there were significant differences in the pod and seed yields among different treatments. High yields of pod and seed (2151and 1467 $\mathrm{kg} / \mathrm{fed}$. respectively) were obtained from $\mathrm{T}_{12}$ (50\% mineral $N+50 \%$ as organic $N+$ cyanobacteria $30 \mathrm{~L} / \mathrm{fed}$ ) followed by $\mathrm{T} 11$ (50\% mineral $\mathrm{N}+50 \%$ as organic $\mathrm{N}+$ cyanobacteria 20L/fed) (2048 and $1373 \mathrm{~kg} / \mathrm{fed}$ respectively) and lowest yield was produced by $\mathrm{T} 6(75 \%$ as organic $\mathrm{N}+$ cyanobacteria 15L/fed) (1279 and 807.94$)$. It was also observed that there were no significant differences between $T_{1}$ and $T_{4}$ as well as $T_{5}$ and $T_{8}$ in seed yield. Also there were no significant differences between $\mathrm{T}_{4}$, $T_{9}$ and $T_{10}$ as well as $T_{2}$ and $T_{7}$ in pod yield. The present results suggest that using the treatments $T_{12}, T_{11}$ or $T_{10}$ gave higher values of seed yield (1467, 1373 and 1293.97 $\mathrm{kg} / \mathrm{fed}$ respectively) than using $100 \%$ mineral $\mathrm{N}$ fertilizer $\mathrm{T}_{1}$ (1245.75 kg/fed). This might be due to the positive effect of inoculation with cyanobacteria in 


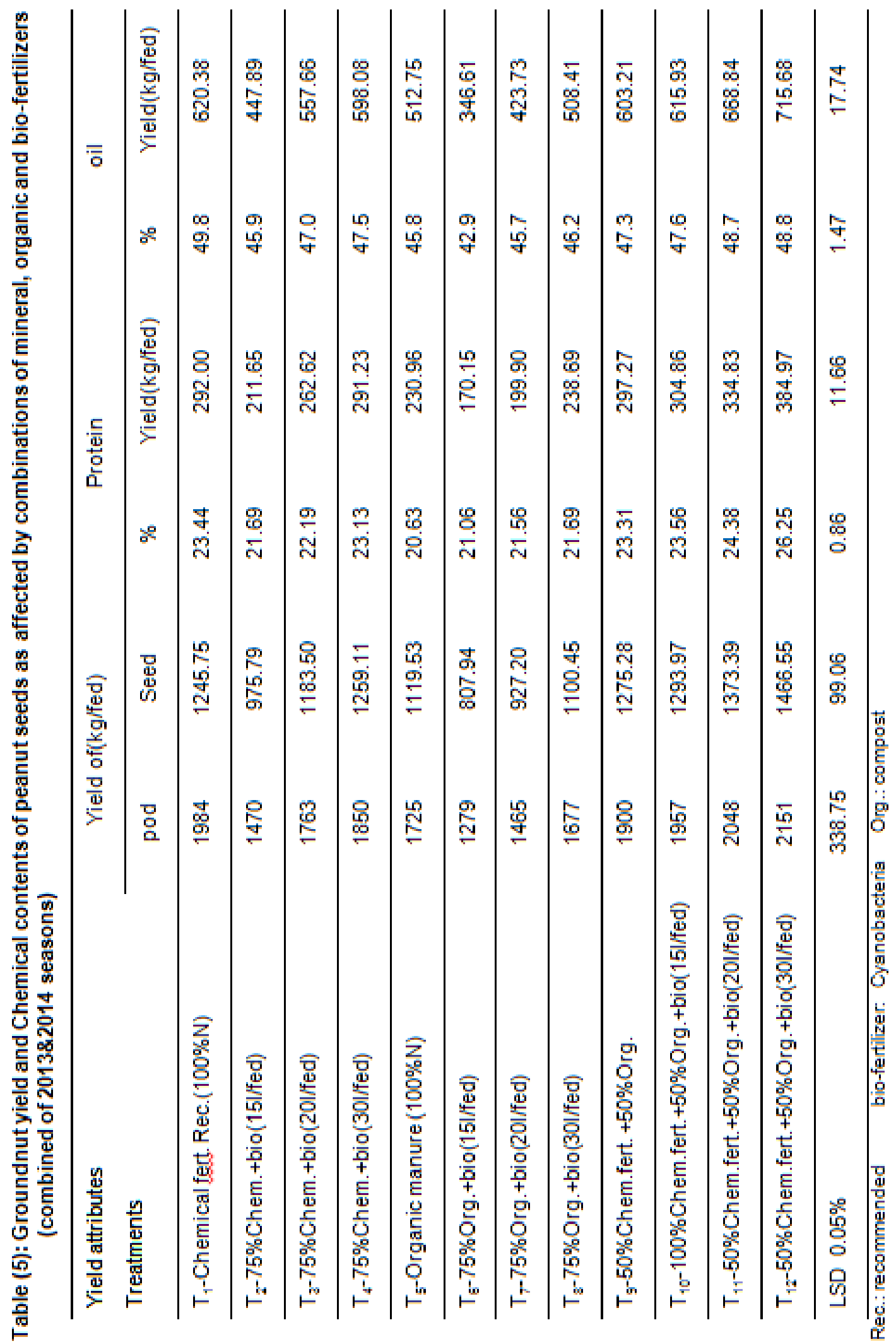




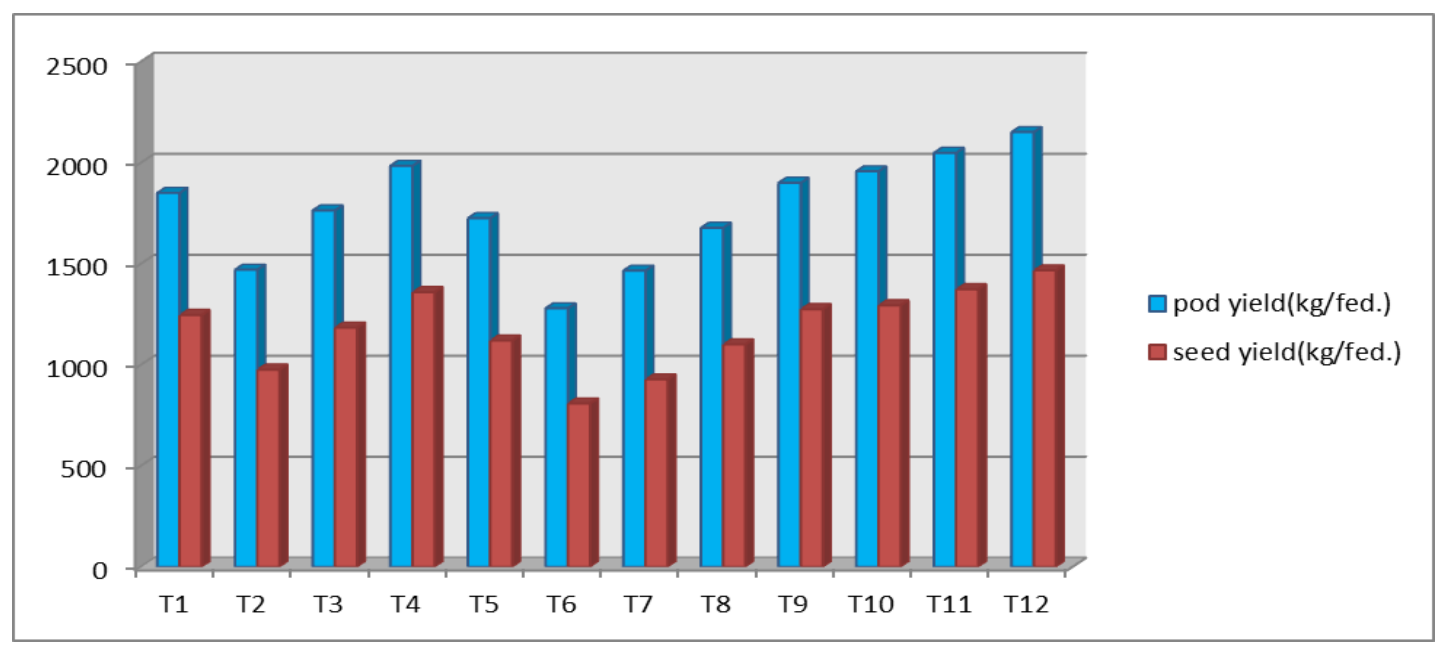

Fig. (2) Effect of treatments on pod and seed yield of peanut

combination with inorganic nitrogen and/or compost on better root development which resulted in more nutrient uptake. These microorganisms also produce vitamins and plant growth promoting substances for the betterment of plant growth. Organic manures not only release nutrients slowly but also prevent the losses of leaching (Anup Das et al. 2010). In this connection, De-Mule et al. (1999) and De-Caire et al. (2000) indicated that blue-green algae excrete many of substances (growth promoting regulators, vitamins, amino acids, polypeptides, antibacterial and polymers, especially exopolysaccharides), which induced a growth promotion of other microorganisms and increased the enzymes activities.

Cyanobacteria also add organic matter, synthesize and liberate amino acids, vitamins and auxins, reduce oxidizable matter content of the soil, provide oxygen to the submerged rhizosphere, ameliorate salinity, buffer the $\mathrm{pH}$, solubilize phosphates and increase the efficiency of fertilizer use in crop plants (Kaushik, 2004).

\section{II -Seed protein content}

Protein percentage in peanut seeds was significantly affected by the applied treatments (Table 5 and Fig. 3) and varied from 20.63 to $26.25 \%$ according to treatments. The highest protein content was obtained with $\mathrm{T}_{12}$ ( $50 \%$ mineral $\mathrm{N}+50 \%$ as organic $\mathrm{N}+$ cyanobacteria $30 \mathrm{~L} / \mathrm{fed}$ ) followed by $\mathrm{T}_{11}(50 \%$ mineral $\mathrm{N}+50 \%$ as organic $\mathrm{N}+$ cyanobacteria 20L/fed) and $\mathrm{T}_{10} \quad(50 \%$ mineral $\mathrm{N}+50 \%$ as organic $\mathrm{N}+$ cyanobacteria $15 \mathrm{~L} / \mathrm{fed}$ ). From Table (5), it is clear that protein content significantly increased with inorganic fertilizer more than organic fertilizer. Protein yield fed ${ }^{-1}$ was also significantly affected by the applied treatments. The favorable effect of $\mathrm{N}$ fertilizer on protein might be explained by assuming an influence of $\mathrm{N}$ availability on critical stage of seeds initiation and development of plant metabolism in away leading to the increase in the synthesis of amino-acid and their incorporation into seed protein.

These results suggest that the high $\mathrm{N}$ increases the amino acids synthesis in the leaves and this stimulate the accumulation of protein in the seed. The significant effect of compost may be due to the fact that this manure consists of different nutritive elements, so, it is considered a balanced fertilizer that encourages the photosynthetic process and other physiological factors that increase protein synthesis. El kramany et al. (2007) reported that protein content increases with improved plant nutrition and that the application of manure results in a high exchangeable capacity, hence a considerable quantity of nitrogen is diverted 
to available form and thus increased protein. Nitrogen is one of the essential nutrients involved as a constituent of bio-molecules such as nucleic acids, coenzymes and proteins and any deviation in these constituents would inhibit the growth and yield of plants. Protein concentrations in plants tend to increase with fertility level of the growth medium. Dixit and Gupta (2000) reported that farmyard manure or bio fertilizer either alone or in combination showed an increasing tendency of protein content in rice grain.Cyanobacteria fertilizer also helps the stabilization of soil, add organic matter, release growth promoting substances, improve the physico-chemical properties of soil and solubilize the insoluble phosphates.

\section{III -Seed oil content}

The applied different treatment combinations caused increases in seeds oil content and oil yield (Table 5) and Fig. (3). $\mathrm{T}_{1}(100 \% \mathrm{~N}$-mineral) recorded the highest oil content (49.8\%), however, a maximum oil yield was recorded by the treatment $T_{12}$ $\left(715.68 \mathrm{~kg} \mathrm{fed}^{-1}\right)$ followed by $T_{11}(668.84 \mathrm{~kg}$ $\left.\mathrm{fed}^{-1}\right)$. This may be due to the improvement in the soil's physical, chemical and biological properties as well as nutritional status due to the addition of cyanobacteria in combination with inorganic nitrogen and/or compost which have contributed to the higher yield. Similar results were also reported by Abd El Rasoul et al. (2002). Increases in seed oil yield $\left(\mathrm{kg} \mathrm{fed}^{-1}\right)$ by cyanobacteria might be due to their positive effect on nutrients absorption, higher photosynthetic rate, higher dry matter accumulation and higher vegetative growth. Nitrogen is an essential nutrient in creating the plant dry matter, as well as many energy-rich compounds which regulate photosynthesis and plant production, thus influencing pod development, increasing the number of pods/plant and pod weight and consequently increases oil yield.

\section{IV- Nutrient concentration and contents of peanut seeds}

Nutrients concentration and contents in seeds of peanut plant (Table 6) and Fig. (4) differs significantly amongst all the treatments. Plants inoculated with cyanobacteria $30 \mathrm{~L} / \mathrm{fed}$ in combination with $50 \%$ mineral $\mathrm{N}+50 \%$ as organic $\mathrm{N}\left(\mathrm{T}_{12}\right)$ followed by $\mathrm{T}_{11},(50 \%$ mineral $\mathrm{N}+50 \%$ as organic $\mathrm{N}+$ cyanobacteria $20 \mathrm{~L} / \mathrm{fed}$ ) and T10 (50\% mineral $\mathrm{N}+50 \%$ as organic $\mathrm{N}+$ cyanobacteria $15 \mathrm{~L} / \mathrm{fed}$ ) increased nutrient content (NPK) compared to $(100 \%$ mineral $\mathrm{N})$. The $\mathrm{N}$ content varied from 36.94 to $61.60 \mathrm{~kg} / \mathrm{fed}$ in favor of $\mathrm{T}_{12}$ which was significantly different from other treatments (Table 6). The maximum $P$ content was obtained from $\mathrm{T}_{12}(50 \%$ mineral $\mathrm{N}+50 \%$ as organic $\mathrm{N}+$ cyanobacteria $30 \mathrm{~L} / \mathrm{fed}$ ) followed by $\mathrm{T}_{11}(50 \%$ mineral $\mathrm{N}+50 \%$ as organic $\mathrm{N}+$ cyanobacteria 20L/fed) and $\mathrm{T}_{10} \quad(50 \%$ mineral $\mathrm{N}+50 \%$ as organic $\mathrm{N}+$ cyanobacteria $15 \mathrm{~L} / \mathrm{fed})$. The highest $\mathrm{K}$ content $\left(14.08 \mathrm{~kg} / \mathrm{fed}\right.$.) was observed in $T_{12}$ followed by $T_{11}(12.91 \mathrm{~kg} / \mathrm{fed})$. The beneficial effects of using organic fertilizers along with mineral $-\mathrm{N}$ fertilizer on increasing nutrient concentration and contents of peanut seeds could be due to their effect on providing plants with their requirements from different nutrients at a longer time as well as their effect on increasing the availability of nutrients in the soil for uptake by plants and enhancing the nutritional status of the plants. Combined application of organic $\mathrm{N}$ with bio fertilizers as a partial substitute for chemical fertilizers was very effective in stimulating nutrient concentration and contents of peanut plant. These results may be due to the ability of bio fertilizer to transport major nutrients like $\mathrm{N}$ and $\mathrm{P}$ besides secreting plant growth promoting substances such as IAA, gibberellins and abscisic acid. Organic acids resulting from organic manure have led to increase in soil acidity and consequently convert insoluble forms of phosphorus into soluble ones (Wani et al. 2007).

Data in (Table 6) exerted that cyanobacteria inoculation with $50 \%$ of the recommended mineral $\mathrm{N}+50 \%$ as organic 
$\mathrm{N}$ significantly increased concentration and contents of $\mathrm{N}, \mathrm{P}$ and $\mathrm{K}$ in peanut seeds as compared with the recommended $\mathrm{N}$ dose only. The activity of soil organisms is very important for ensuring sufficient nutrient supply to the plant. If the microorganisms find suitable conditions for their growth, they can be very efficient in dissolving nutrients and making them available to plants. Increases in N, P and $\mathrm{K}$ concentration were $7.2,20.9$ and $4.35 \%$ and those in contents were $31.85,42.40$ and $22.86 \%$, respectively, compared with the recommended $\mathrm{N}$ chemical dose only. The positive effect of cyanobacteria inoculation upon nutrient uptake could be described to the high efficiency of bacteria presence in these bio fertilizers to fix atmospheric nitrogen and /or to produce some biologically active substances, e.g., IAA, gibberellins and cytokinins. Such substances would help in increasing the root biomass and thus indirectly help in greater absorption of nutrients from surrounding environment ( $E I$ kramany et al. 2007). There was a remarkable promotion on chemical quality parameters with increasing cyanobacteria concentrations from 15 to $30 \mathrm{~L} / \mathrm{fed}$ as soil drench.

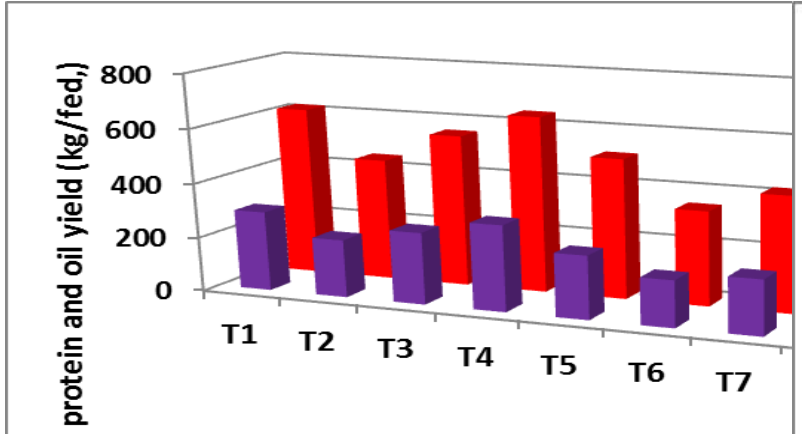

Fig. (3) protein and oil yield ( $\mathrm{kg} / \mathrm{fed}$,): combinations of chemical, organic anc

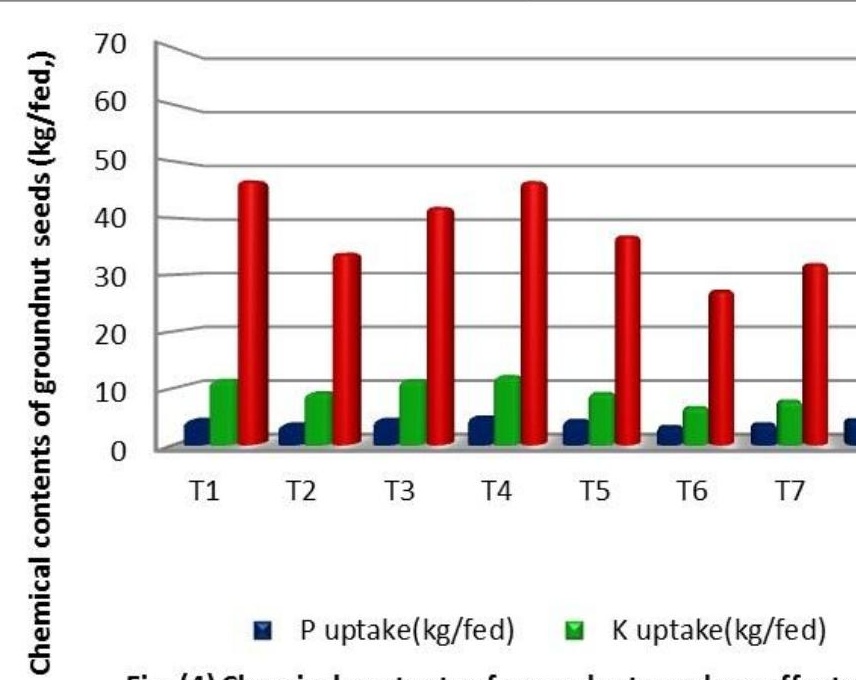

Fig. (4) Chemical contents of groundnut seeds as affecte organic and bio-fertilizers 


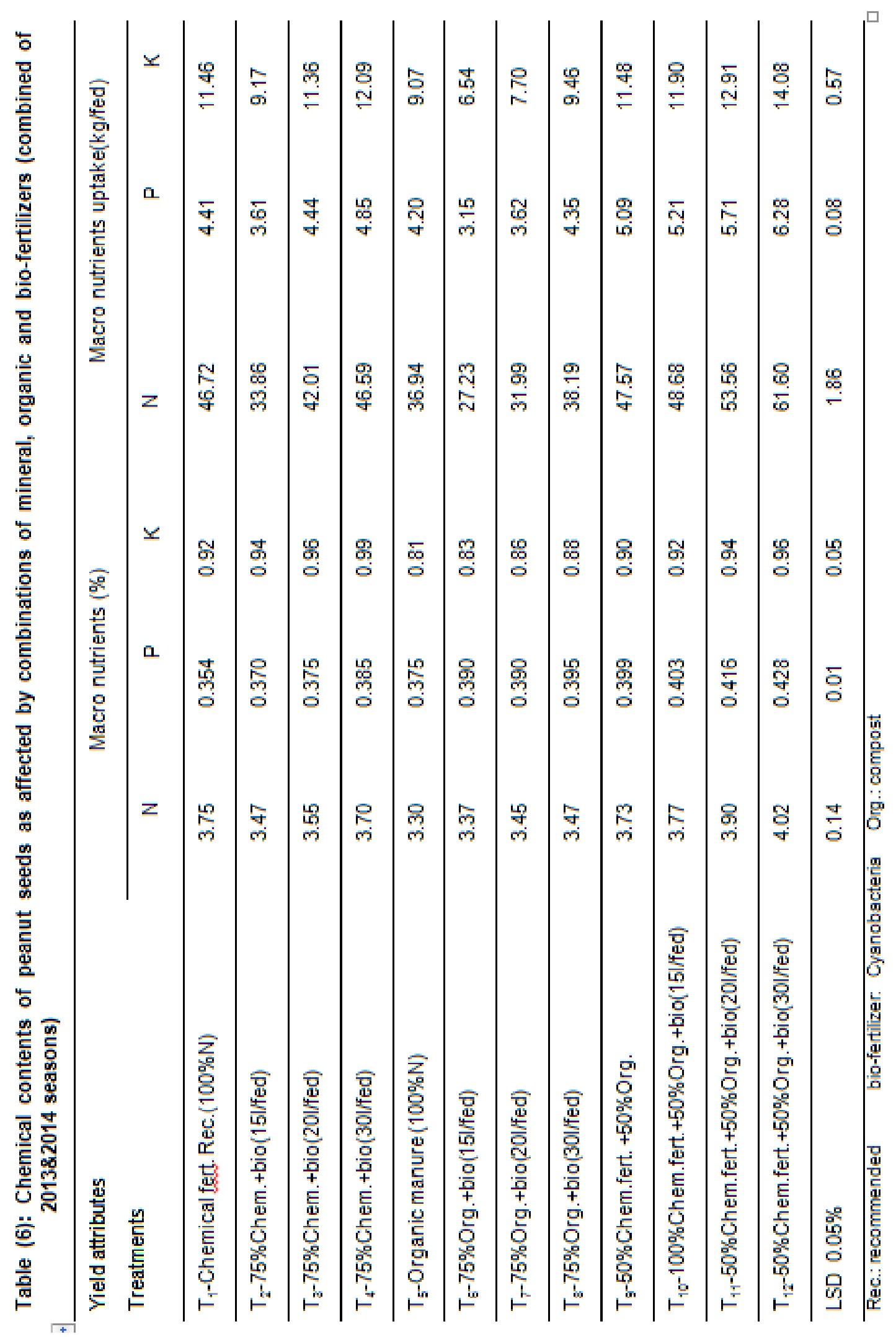




\section{V-Soil biological activity}

Data in Table (7) indicate the effect of inoculation with cyanobacteria combined with $\mathrm{N}$ - mineral and/or compost combined with cyanobacteria on the soil biological activity in terms of total count bacteria, cyanobacteria counts, $\mathrm{CO}_{2}$ evolution, dehydrogenase and nitrogenase activity. Cyanobacteria inoculation, generally, enhanced the soil biological activity in terms of increasing the $\mathrm{CO}_{2}$ evolution, dehydrogenase activity, nitrogenase, total cyanobacteria counts and total bacterial counts under both levels of nitrogen (75 and $50 \% \mathrm{~N})$ compared to the untreated treatments $(100 \%$ mineral $\mathrm{N})$. The maximum microbial activity was achieved by the combined effect of soil drench application with $75 \%$ as organic $\mathrm{N}$ followed by $75 \%$ mineral $\mathrm{N}$. These results are in agreement with those of Mahmoud et al. (2007) who stated that cyanobacteria inoculation generally enhanced the soil biological activity. However, the use of $50 \%$ mineral $\mathrm{N}$ $+50 \%$ as organic $\mathrm{N}$ with $30 \mathrm{~L} / \mathrm{fed}$ cyanobacteria gave the highest values of total count bacteria, $\mathrm{CO} 2$ evolution, dehydrogenase activity and nitrogenase activity in peanut soil. Caire et al. (2000) established that cyanobacteria can increase the soil enzymatic activity. Aref and ElKassas (2006) found that cyanobacteria inoculation to maize field enhanced significantly any of total count bacteria, cyanobacteria count, $\mathrm{CO}_{2}$ evolution, dehydrogenase and nitrogenase activities compared to the control treatment received no inoculation. They explained that bio fertilization with cyanobacteria led to increase microorganisms' community and in turn soil biological activity in soil through increasing the organic matter and microbial activity.

In conclusion, results from the present study indicate that the application of cyanobacteria and compost fertilizer can positively affect the peanut yield and its attributes, especially for the treatment received $50 \%$ mineral $\mathrm{N}+50 \%$ as organic $\mathrm{N}$ + cyanobacteria $30 \mathrm{~L} / \mathrm{fed}$ ). which can reduce the need for chemical fertilizers and subsequently reduce environmental pollution compared with other mineral chemical fertilizers.

\section{CONCLUSION}

In conclusion, the results of the present investigation revealed beneficial role of cyanobacteria in improving the status of the soil in terms of physical, chemical and nutritional properties. Hence, cyanobacteria bio fertilizers are recommended to be used as renewable natural nitrogen resources for different crop plants in agriculture. They are non-polluting, inexpensive; utilize renewable resources in addition to their ability in using free available solar energy, atmospheric nitrogen and water. The findings of this study have clearly showed that combined application of cyanobacteria along with $50 \%$ recommended dose of mineral $\mathrm{N}+50 \%$ as organic $\mathrm{N}$ has resulted in obtaining the highest plant growth, yield and yield attributes. This combination may also reduce $50 \%$ the amount and cost of $\mathrm{N}$ mineral fertilizer application in peanut under sandy soil conditions and finally sustain the soil health.

\section{REFERENCES}

Abd El-Moniem Eman, A., A.S.E. Abd-Allah and M.A. Ahmed (2008). The combined effect of some organic manures, mineral $\mathrm{N}$ fertilizers and algal cells extract on yield and fruit quality of williams banana plants. American-Eurasian J. Agric. Environ. Sci., 4: 417-426.

AbdEl Rasoul, Sh. M., A.A. El Banna, M.M. Abdel Moniem and A.A. Amer (2002). Bio and organic fertilization of peanut plant grown on new reclaimed sandy soil. Egypt. J. Appli. Sci., 17: 127-142.

Anup Das, C. M. Gour, P. P. Dharmendra, G. Probir Kumar, N. Shishomvanao and B. Pankaj (2010). Productivity, nutrient uptake and postharvest soil fertility in lowland rice as influenced by composts 


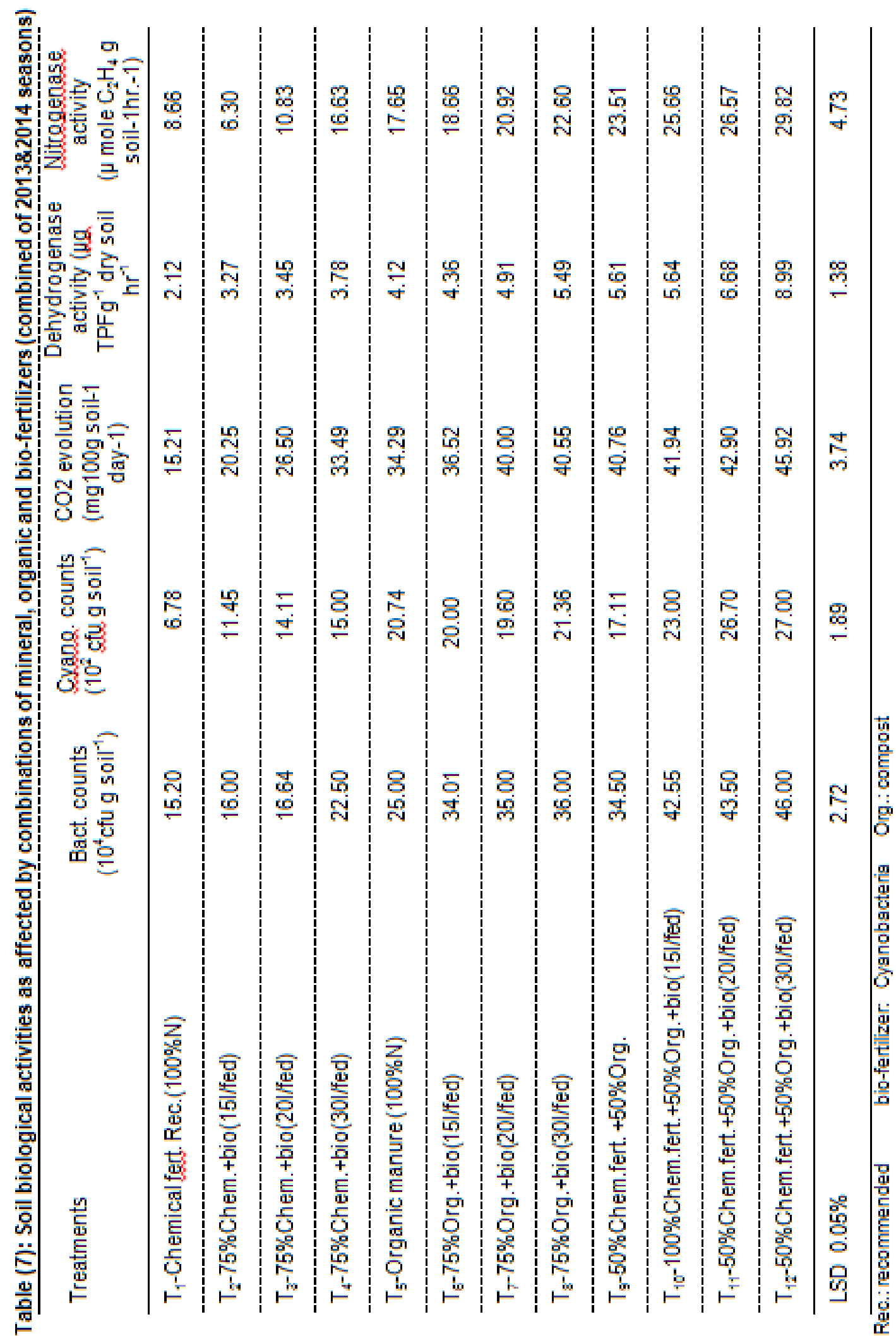


made from locally available plant biomass. Arch.of Agron. Soil Sci., 56 (6):671-680 .

Aref Elham, M. and A. R. El-Kassas (2006). Cyanobacteria inoculation as nitrogen source may substitute partially mineral nitrogen in maize production. J. Agric. Sci. Mansoura Univ., 31: 5367 - 5378.

A.O.A.C. (1990). Official Methods of Analysis of the Association of Official Agriculture Chemists.Published by Association of Official Agriculture Chemists, $13^{\text {th }}$ Ed. Washington, D.C., USA.

APHA, American Public Health Association (1992). Standard Methods Examination of Wastewater, $17^{\text {th }}$ ed. American Public Health Association, Washington D.C., p. 116.

Badawy, A.M., T.M. EL-Katony, M.S. Serag and M.A. Mousa (1996). Potentiality of Azolla filiculoides Lam. for nitrogen fixation and its use as bio fertilizer for rice. Egypt. J. Bot. 36: 109-128.

Boroomandan, P., M. Khoramivafa, Y. Haghi and A. Ebrahimi (2009). The effects of nitrogen starter fertilizer and plant density on yield, yield components and oil and protein content of soybean (Glycine max, Merr.). Pakistan Journal of biological sciences, vol 12, (4): 378-382.

Caire, G. Z. D., M. S. De Cano, R. M. Palma and C. Z. De Mulé (2000). Changes in soil enzyme activities following additions of cyanobacteria biomass and exopolyssacharide. Soil Biol. Biochem., 32: 1985-1987.

Casida, L. E., D.A. Klein and T. Santoro (1964). Soil dehydrogenase activity. Soil Sci., 98: 371-376.

Chapman, H.D. and P.F. Pratt (1961). Methods of Analysis for Soils, Plants and Water. Belmont: Wadsworth Publishing Company, Californian Division of Agriculture Science, 309p.

Dart, P.J., J.M. Day and D. Harris (1972). Assay of nitrogenase activity by acetylene reduction. In: Use of isotopes for study of fertilizer utilization by legume crops. FAO/IAEA Technical Report Series, 149: 85-97.

De-Caire, G.Z., M.M. Storn de Cano, R.M. Palma and M.C. Zaccaro (2000). Changes in soil enzymes activity by cyanobacteria biomass and exopolysaccharide. Soil Biol. and Biochem. In press.

De-Mule, M.C.Z., de G.Z. Caire, de M.S. Cano, R.M. Palma and K. Colombo (1999). Effect of cyanobacterial inoculation and fertilizers on rice seedlings and post-harvest soil structure. Comm. Soil Sci. Plant Anal., 30: 97-107.

Dixit, K.G. and B.R. Gupta (2000). Effect of FYM, chemical and bio-fertilizers on yield and quality of rice and soil properties. J. Indian Soc. Soil Sci., 48 (4): 773-780.

El Gaml, M. (2006). Studies on cyanobacteria and their effect on some soil properties. M.Sc. Thesis Soil Dept. Faculty of Agric., Banha, Univ. Kalubia Governorate, Egypt.

El-Kholy, M. A., S. El-Ashry and A. M. Gomaa (2005). Bio fertilization of maize crop and its impact on yield and grains nutrient content under low rates of mineral fertilizers. J. Appl. Sci. Res., 1: 117-121.

El-Kramany, M.F., A. Amany Bahr, F. Manal Mohamed and M.O. Kabesh (2007). Utilization of bio-fertilizers in field crops production 16-groundnut yield, its components and seeds content as affected by partial replacement of chemical fertilizers by bio- organic fertilizers. J. Applied Sciences Research, $3(1): 25-29$.

Fageria, N.K., V.C. Ballgar and C.A. Johanes (1997). Growth and Mineral Nutrient of Field Crop, second ed. Marcel Dekker. Inc., New York, USA, p. 494.

Gaur, A.C., K.V. Sadasivan, O.P. Vimal and R.S. Mathur (1971). A study of decomposition of organic matter in an alluvial soil. $\mathrm{CO}_{2}$ evolution, microbiological and chemical transformation. Plant and Soil, 34:17-28. 
Hassan, A., A. El- Sayeda, F.T. Mikhaeel and F.M. Ghazal (2008). Effect of cyanobacteria inoculation in presence or absence of different nitrogen levels on maize, yield components, soil biological activity and soil native mycorrhizae. J. Agric. Sci. Mansoura University 33:91719182

Kaushik, B. D. (2004). Use of Blue-Green Algae and Azolla Biofertilizers in Rice Cultivation and Their Influence on Soil Properties. pp 166-184 in P. C. Jain (ed.), Microbiology and Biotechnology for Sustainable Development. CBS Publishers \& Distributors, New Delhi, India.

Leduy, A. and N. Therien (1977). An improved method for optical density measurement of semimcro blue-green alga Spirulina maxima. Biotechnol. Bioeng., 19:1219-1224.

Mahmoud, A.A., Soha S.M. Mostafa, A.M. Abd El-All Azza and A.Z. Hegazi (2007). Effect of cyanobacteria inoculation in presence of organic and inorganic amendments on carrot yield and sandy soil properties under drip irrigation regime. Egypt. J. Appl. Sci., 22(12B): 716-733.

Maqubela, M. P. and P. N. S. Menkeni (2009). Nostoc cyanobacterial inoculation in South African agricultural soils enhances soil structure, fertility and maize growth. Plant Soil. 315:79 - 92.

Marschner, H. (1995). Mineral Nutrition in Higher Plants. Academic Press, London.

Mishra, U. and S. Pabbi (2004). Cyanobacteria: A potential bio fertilizer for rice. Resonance 6:6 -10

Page, A.L., R.H. Miller and D.R. Keeney (1982). Methods of Soil Analysis. Part 2. Chemical and Microbiological Properties. American Society of Agronomy, Madison Wisconsin. USA, pp.595-624.

Piper, C.S. (1950). Soil and Plant Analysis, First ed. Interscience Publishers Inc., New York, USA, pp. 30-229.

Rechcigl, J. E. (1995). Soil Amend and Environmental Quality. Lewis Publishers is an important of CRC Press, $1995 \mathrm{P}$. 489.

Rippka, R., J. Deruelles, J.B. Waterburg, M. Herdman and R.Y. Stanier (1979). Generic assignments, strain histories and properties of pure cultures of cyanobacteira. J. of General Microbiol. 111: 1-16.

Roger, P.A. and P.A. Reynaud (1982). Freeliving Blue-green Algae in Tropical Soils. Martinus Nijh off Publisher, La Hague.

Snedecor, G.A. and W.G., Cochran, (1980). Statistical Methods, seventh Ed. lowa State Univ. Press, Ames, lowa, USA, pp. 255-269.

Stanier, R.Y., R. Kunisawa, M. Mandel and G. Cohen-Bazire (1971). Purification and properties of unicellular blue-green algae (Order Chroococcales), Bacteriol. Rev., 3: 1711-20.5.

Vonshak, A. (1986). Laboratory Techniques for the Cultivation of Microalgae. In Handbook of microalgae mass culture. (Ed. A. Richmond). Boca Raton: CRC Press.

Vonshak, A. and A. Richmond (1988). Mass production of the blue-green algae Spirulina. An Overview. Biomass. 15:233-247.

Wani, P.A., M.S. Khan and A. Zaidi (2007). Synergistic effects of the inoculation with nitrogen-fixing and phosphate-solubilizing rhizobacteria on the performance of fieldgrown chickpea. Plant Nut. Soil Sci., 170: 283-287.

Zaki, M.F., A.A.M. Abdelhafez and Camilia Y. Eldewiny (2010). Influence of bio fertilization and nitrogen sources on growth, yield and quality of broccoli (Brassica oleracea var. italiaca). Egypt. J. Appl. Sci., 24(3): 14-39.

Zarrouk, C. (1966). Contribution á l'étude d'une cyanophycée. Influence de diver's facteurs physiques et chimiques sur la croissance et la photosynthése de Spirulina maxima (Setch. ET Gardner) Geitler. Ph. D. Thesis, University of Paris, France. 
تأثير التسميد النيتروجين العضوى والحيوى كبديل جزئى للنيتروجين المعدنى على محصول الفول السودانى و مكوناته

\section{ماجدة على عويس ، سحرمحمد زكريا ، سها سيل محمد مصطفى}

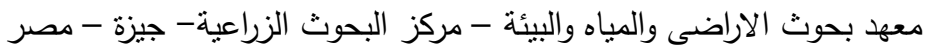

أجريت تجربة حقلية بمحطة بحوث الإسماعيلية بمركز البحوث الزراعية خلال موسمين متتالين 2014/2013 وذلك لدراسة أثز التلقيح بالسيانوبكتريا المثبتة للنيتروجين بمعدلات مختلفة بمصاحبة مستويات بهرية

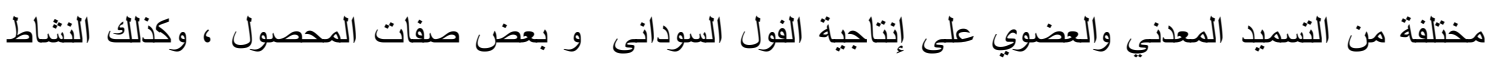
الحيوي على التربة الرملية .

أوضحت النتائج أن التلقيح بالسيانوبكتريا في وجود التسميد المعدني أو العضوي لعب دوراً هاماً في زيادة وجودة المحصول وكذلك أدى إلى تحسين التربة الرملية . إضافة سلالات من السيانوبكتريا لنبات الفول السودانى أظهر فائدة اقتصادية حيث أمكن توفير حوالي 50\%

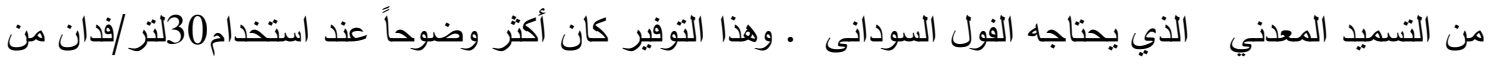
السيانوبكتربا المثبتة للنيتروجين حيث ، كانت هناك زيادة معنوية ملحوظة في إنتاجية محصول الفول السودانى عن تلك المتحصل عليها باستخدام كمية التسميد المعدني أو العضوي الموصى بها منفردة. وكذللك أدى التلقيح بالسيانوبكتريا بصفة عامة إلى تحسين النشاط البيولوجي للتربة الرملية، وقد اتضح ذللك في

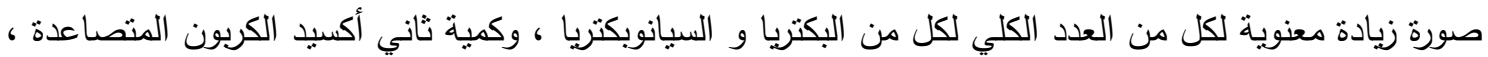
نشاط كل من انزيمي الديهيدروجينيز والنيتروجينيز • أدى الثلقيح بالسيانوبكتريا المثبتة للنيتروجين في وجود التسميد العضوى إلى زيادة معنوية في كل من النيتروجين والفوسفور والبوتاسيوم في الحبوب مقارنة بالغير ملقحة . هذه الدراسة تهدف إلى زيادة الاهتمام بتطبيق تكنولوجيا التسميد بالسيانوبكتريا لمحاصيل البقوليات والذي يؤدى إلى تقليل الاعتماد على السماد المعدني المكلف للزارع والملوث للبيئة وزيادة الاتجاه إلى التسميد العضوى. 